\title{
Mensuração, controle e planejamento de custos em uma propriedade de bovinos de corte
}

Daniela dos Santos de Oliveira"João Henrique Zancanaro, Ronaldo Bernadon Meireles, Flávio Carlos Barro, Eduardo Schorr, Diego Antonio Remboski, Flaviomar Sonálio, Leandro Rosa, Rafael Camargo.

Faculdades IDEAU, Getúlio Vargas, RS, Brasil

*Autor correspondente

e-mail: veterinaria.gv@ideau.com.br

\section{Resumo}

A bovinocultura de corte vive um período turbulento; enquanto o mercado interno enfrenta elevação nos custos de produção, cresce a demanda nas exportações, influenciando os pecuaristas a investirem continuamente na atividade. 0 cultivo de Trigo de Duplo Propósito (TDP) permite reduzir os custos de produção de carne e otimizar os recursos na propriedade, aumentando a renda por unidade de área. A comercialização da carne produzida em sistema de pastejo direto continua tendo boa rentabilidade apesar da atual conjuntura econômica brasileira;, o cultivo de TDP, ainda que com custo elevado, resulta em uma boa fonte alternativa para alimentação. Objetivando avaliar os custos e rentabilidade da produção de carne, conduziu-se este trabalho em setembro e outubro de 2015 , onde avaliou-se ganho de peso de novilhos castardos e inteiros manejados em TDP. Os custos de aquisição de 25 animais foi de R\$33.644,00, frete de $\mathrm{R} \$ 600,00$ e R\$ 142,00 para brincagem. Para castração de 12 dos 25 animais, a anestesia, fio para o corte e algodão antisséptico custaram R 8,25 por animal. O TDP foi cultivado em 16 ha $^{-1}$ ao custo de R $\$ 1.100,00$ $\mathrm{ha}^{-1}$, onde os animais permaneciam por quatro horas e trinta minutos diariamente, recebendo em seguida no cocho $2 \mathrm{~kg}$ de ração com 16\% de proteína e $70 \mathrm{~m} / \mathrm{g}$ de ionoforo (monensina) por animal. Ao final do ciclo foi realizada a colheita do trigo obtendo-se em média 35 sacas ha ${ }^{-1}$, e receita total de $\mathrm{R} \$ 16.800,00$, deixando um défict de $\mathrm{R} \$ 800,00$. 0 ganho de peso dos animais foi acompanhodo através de quatro pesagens realizadas com intervalos de 15 dias, onde observou-se ganho de peso maior nos animais inteiros. Para cada quilo de peso ganho, no castrado haverá mais tecido adiposo do que muscular, onde a gordura possui mais que o dobro de energia que a musculatura, assim, o animal castrado necessita ingerir uma dieta com muito mais energia ou maior quantidade de alimento em relação ao inteiro para o mesomo rendimento. 0 animal castrado precisa ingerir 15 a 20\% a mais de energia que o inteiro para ganhar o mesmo peso. Observou-se incremento total nos 25 animais após o período de engorda de $5.355 \mathrm{~kg}$, obtendo receita de $\mathrm{R} \$ 51.686,46 \mathrm{na}$ 
venda destes. O lucro dos animais castrados foi de $\mathrm{R} \$$ 6.682,12 e dos inteiros foi de $\mathrm{R} \$ 7.917,30$. 0 resultado econômico final do experimento foi positivo, mostrando que os objetivos foram alcançados apesar da colheita do trigo não ter sido satisfatória e ter gerado resultado econômico negativo; porém, o trigo possui grande valor nutricional para alimentação animal e permitiu desempenho e características de carcaça tidos como satisfatórios. A partir das análises, pode-se observar que o método de engorda adotado neste estudo foi financeiramente viável e permitiu agregar renda à atividade do produtor rural. 